\title{
CANDI SIMANGAMBAT SEBAGAI MEDIA MEMBANGUN KARAKTER PESERTA DIDIK YANG CINTA PENINGGALAN BERSEJARAH
}

\author{
Suratno \\ Institut Kesehatan Deli Husada Deli Tua \\ suratno69@gmail.com
}

\begin{abstract}
Abstrak
Penunjang dasar tercapainya tujuan pendidikan nasional Indonesia yaitu tercapainya tujuan instruksional khusus dan salah satu penunjang tercapainya tujuan ini adalah penggunaan media pembelajaran yang dipergunakan oleh guru saat proses belajar-mengajar. Salah satu media pembelajaran yang dapat dipergunakan oleh guru adalah situs cagar budaya dan salah satu contohnya adalah candi Simangambat. Metode penelitian yang digunakan adalah metode kualitatif dengan teknik pengumpulan data melalui observasi, wawancara, dan dokumentasi. Hasil penelitian menunjukan bahwa Candi Simangambat dapat dipergunakan sebagai media pembelajaran dalam membangun karakter peserta didik untuk mencintai bangunan bersejarah. Pemanfaatan situs cagar budaya sebagai media pembelajaran saat proses belajar-mengajar harus mendapat dukungan dan izin dari pejabat atau pihak terkait dan berwenang dalam pelenggaraan pendidikan.
\end{abstract}

Kata kunci: Candi Simangambat, Karakter, Peserta Didik

\begin{abstract}
The basic support for achieving Indonesia's national education goals is the achievement of specific instructional objectives and one of the supporting achievements of this goal is the use of learning media used by teachers during the teaching and learning process. One of the learning media that can be used by teachers is a cultural heritage site and one example is Simangambat temple. The research method used is qualitative method with data collection techniques through observation, interview, and documentation. The results showed that Simangambat Temple can be used as a learning medium in building the character of students to love historical buildings. The use of cultural heritage sites as a learning medium during the teaching and learning process must get support and permission from officials or related parties and authorities in the implementation of education.
\end{abstract}

Keywords: Simangambat Temple, Character, Learners

\section{PENDAHULUAN}

Provinsi Sumatera Utara merupakan salah satu provinsi yang memiliki banyak peninggalan bersejarah di Indonesia. Bentuk dan jenisnya beraneka ragam, seperti rumah tradisional, situs makam kuno, kompleks batu megalit, candi dll. Peninggalan bersearah tersebut sebahagian besar sudah mendapat perhatian sekaligus perlindungan dari pemerintah pusat melalui Menteri Kebudayaan dan Pariwisata.

Salah satu peninggalan bersejarah yang ada di Sumatera Utara adalah candi Simangambat yang berlokasi di Kelurahan Simangambat, Kecamatan Siabu, Kabupaten Mandailing Natal, Provinsi Sumatera Utara.
Menurut Undang-undang Nomor:11Tahun 2011 kompleks candi Simangambat masuk dalam kategori situs cagar budaya. situs cagar budaya adalah lokasi yang berada di darat dan/atau di air yang mengandung Benda Cagar Budaya, Bangunan Cagar Budaya, dan/atau Struktur Cagar Budaya sebagai hasil kegiatan manusia atau bukti kejadian pada masa lalu [pasal 1 ayat 5 UU No. 11 tahun 2011].

Candi Simangambat berdiri pada abad ke-9 masehi hal ini sebagaiman ditegaskan oleh Askolani Nasution praktisi seni dan budaya Kabupaten Mandaiing Natal, Provinsi Sumatera Utara. Bagaimanapun kondisi candi Simangambat dapat diberdayakan untuk berbagai kepentingan 
positif seperti untuk peneliti dan pendidikan.

Sebagai situs cagar budaya candi Simangambat cukup ideal dijadikan media pembelajaran untuk membangun karakter peserta didik. Membangun dalam kamus besar bahasa Indonesia salah satu artinya adalah membina. Dari defenisi tersebut dapat disimulkan bahwa membangun karakter peserta didik adalah membina karakter peserta didik ke arah yang baik melalui proses belajar-mengajar. Salah satu karakter dimaksud adalah mencintai peninggalan bersejarah.

Karakter adalah sifat, watak akhlak ataupun kepribadian seorang individu yang membendakannya dengan individu yang lain (Nurgiansah, 2021). Karakter merupakan keseluruhan disposisi kodrati dan disposisi yang telah dikuasai secara stabil yang mendefinisikan seorang individu dalam keseluruhan tata perilaku psikisnya yang menjadikannya tipikal dalam cara berpikir dan bertindak [Putry, Raihan, 2018].

Peserta didik adalah anggota masyarakat yang berusaha mengembangkan potensi diri melalui proses pembelajaran yang tersedia pada jalur, jenjang, dan jenis pendidikan tertentu [pasal 1 ayat 4, UU No. 20 Tahun 2003].

Rumusan dari penelitian ini adalah bagaimanakah caranya menjadikan candi Simangambat sebagai media membangun karakter mencintai peninggalan bersejarah pada peserta didik? Secara khusus dan intensif penelitian terhadap candi Simangambat dilakukan oleh Balai Arkeologi Medan. Lembaga ini melakukan pemelitiam pada Maret 2008. Kemudian Agustus 2008 penelitian ini diteruskan oleh Pusat Penelitian dan Pengembangan Arkeologi Nasional dan pada tahun 2009 kegiatan penelitian oleh tim gabungan Balai Arkeologi Medan dan Pusat Penelitian dan Pengembangan Arkeologi Nasional. Candi Simangambat awalnya ditemukan oleh
Schnitger tahun 1937 dan bangunan candi sudah runtuh [Ery Soedewo Andri Restiyadi, 2018, 117-119]. Kegiatan utama lembaga ini di situs candi Simangambat adalah melakukan penggalian di titik-titik yang sudah ditentukan tujuannya adalah: [1] untuk mendapatkan gambaran bentuk asli bangunan candi Simangambat, [2] menemukan bahan-bahan untuk membuat candi Simangambat sekaligus asal usul bahan yang digunakan untuk membangun candi Simangambat, [3] menemukan model arsitektur bangunan candi Simangambat.

\section{METODE PENELITIAN}

Penelitian ini adalah penelitian kualitatit. Penelitian kualitatif adalah pengumpulan data pada suatu latar belakang alamiah, dengan maksud menafsirkan fenomena yang terjadi dan dilakukan dengan jalan melibatkan berbagai metode yang ada [Denzin \& Lincoln dalam Moleong; 2011; 5]. Berdasarkan pengertian tersebut maka penelitian ini dalam pelaksanaannya berpedoman pada langkah-langkah berikut ini yaitu: pertama observasi; observasi ini dilakukan dengan melihat secara langsung obyek penelitian dan dalam hal ini adalah kompleks candi Simangambat, kedua wawancara; wawancara dilakukan dengan mewawancarai informan dan tujuannya adalah untuk mendapatkan keterangan dan penjelasan tentang candi Simangambat, ketiga studi literatur; membaca jurnal yang mengkaji tentang candi Simangambat sekaligus menjadikan rujukan bagi artikel ini dan keempat dokumentasi; langkah ini yaitu dengan mengambil gambar atau foto kompleks candi Simangambat. 


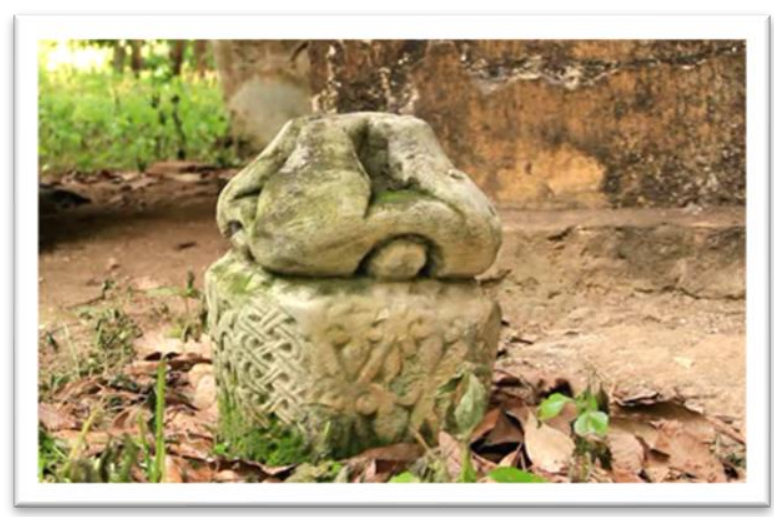

Gambar 1. Salah Satu Arca Candi di Kompleks Candi Simangambat

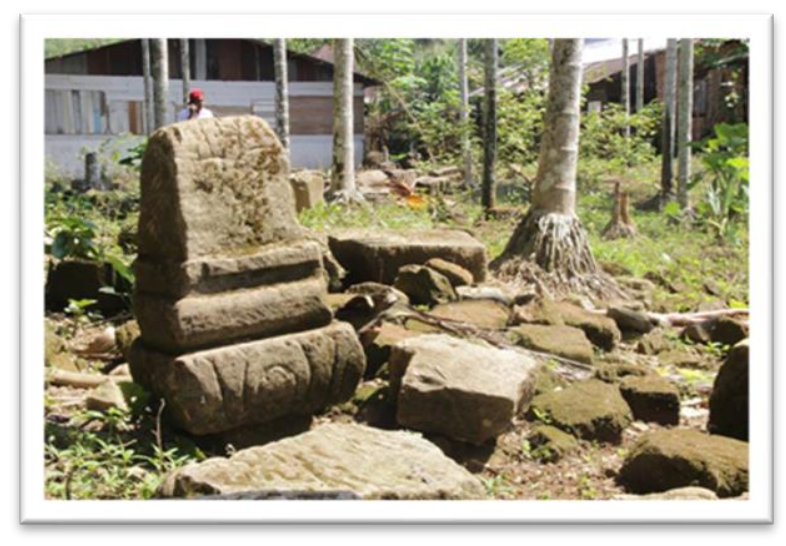

Gambar 2. Kondisi Komleks Candi Simangambat Terkini

\section{HASIL PENELITIAN DAN PEMBAHASAN Hasil Penelitian}

Penelitian ini dilakukan pada kompleks candi Simangambat yang berlokasi di Kelurahan Simangambat, Kecamatan Siabu, Kabupaten Mandailing Natal, Provinsi Sumatera Utara. Setelah dilakukan studi lapangan didapat beberapa data yaitu: [1] candi Simangambat sudah rata dengan tanah; [2] kompleks candi Simangambat dikuasai oleh masyarakat dan dijadikan lahan bercocok tanam; [3] akan menelan biaya yang sangat besar; [4] bentuk candi Simangambat, [5] pemanfaatan situs candi Simangambat sebagai media membangun karakter peserta didik mencintai peninggaan bersejarah.

\section{Pembahasan}

Pembahasan ini berdasarkan datadata hasil-hasil studi lapangan yakni:

1. Candi Simangambat sudah rata dengan tanah; berdasarkan obsevasi langsung yang telah dilakukan kondisi candi Simangambat kondisinya sudah tidak utuh lagi karena sudah runtuh dan rata dengan tanah. Pihak Balai Arkeologi saat melakuan penggalian secara garis besar menemukan dua hal yang disebut dengan artepaktual atau hal-hal yang berhubungan dengan artepak dan non artepaktual. Atau benda-benda yang tidak berhubungan dengan artefak [ Ery Soedewo \& Andri Restiyadi, 2018, 117 ].

2. Tanah lokasi candi Simangambat dikuasai atau dimiliki secara pribadi; sampai saat ini belum ada upaya pembebasan lahan atau ganti rugi lahan tempat candi Simangambat berada oleh pihak manapun, baik pemerintah pusat atau pemerintah daerah. Kedepannya dikhawatirkan hal ini bisa menjadi konflik antara penguasa lahan kompleks candi Simangambat dengan pemerintah.

3. Akan menelan biaya yang sangat besar; untuk memugar ataupun membangun kembali candi Simangambat merupakan pekerjaan yang sulit dan juga memakan biaya yang sangat besar dan mahal. Pembangunan kembali candi Simangambat tidaklah memungkinkan karena di sekitar lokasi kompleks candi Simangambat warga masyarakatnya beragama Islam semua dan tidak terdapat masyarakat yang menganut agama Hindu,

4. Bentuk candi Simangambat; untuk bentuk bangunan candi Simangambat telah berhasil dibuat rekonstruksinya pada gambar berikut: 


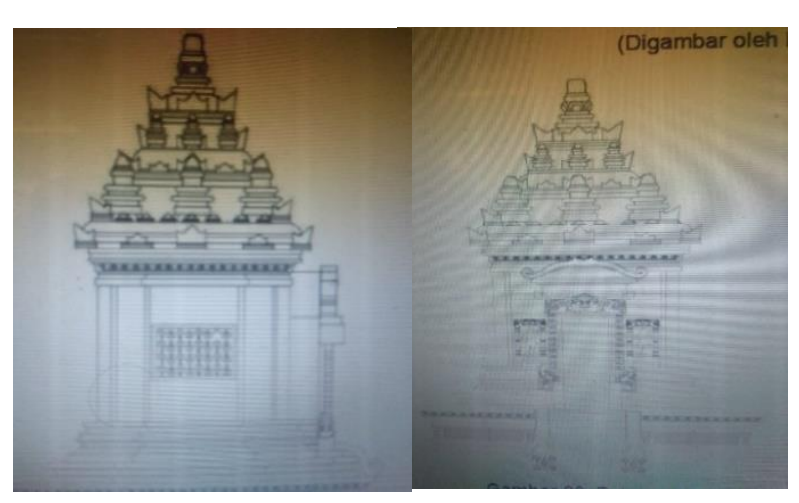

Gambar 3. Rekonstruksi Candi Simangambat Karya Andri Restiyadi

5. Pemanfaatan situs candi Simangambat sebagai media membangun karakter peserta didik mencintai peninggaan bersejarah; untuk mengggunakan situs ini sebagai media membangun karakter peserta didik mencintai peninggalan bersejarah maka ada faktor-faktor yang mendasar dan harus diperhatikan atau dipertimbangkan yaitu:

a. Usia peserta didik; pada dasarnya peserta didik dari tingkat SD s/d peserta didik tingkat SLTA bisa mengikuti kegiatan belajar-mengajar saat digunakannya situs candi Simangambat sebagai medianya. Khusus untuk peserta didik dari kalangan tingkat SD maka guru kelas harus dibantu dan berkolaborasi dengan guru agama, olah raga/pendidikan jasmani karena di tingkat SD menerapkan sistem guru kelas maksudnya adalah selain bidang studi agama dan pendidikan jasmani maka bidang studi lainnya diajarkan oleh guru kelas. Saat membawa peserta didik ke situs candi Simangambat maka guru kelas harus dibantu oleh guru lainnya. Untuk tingkat SD jumlah gurunya minimal 2 orang.

b. Untuk peserta didik dari kalangan SLTP dan SLTA tidak begitu membuat guru sibuk mengawasi karena mereka lebih mudah untuk diarahkan karena peserta didik di usia ini sudah lebih dewasa pemikiranna dan juga mereka sudah bisa mengurangi dunia bermainnya.

c. Jumlah peserta didik; untuk jumlah peserta didik tergantung tingkatan sekolahnya. Untuk peserta didik yang masih duduk di SD maka cukup satu kelas dan untuk peserta didik yang duduk di bangku SLTP dan SLTA maka bisa lebih dari satu kelas tergantung dari kesanggupan guru dan kesepakatan dengan orang tua peserta didik.

d. Jarak tempuh; untuk jarak tempuh yang ideal yaitu sejauh $80 \mathrm{~km}$ karena dengan jarak tersebut kondisi fisik peserta tidak terlalu letih. Jarak tempauh memiliki peran penting untuk itu maka pihak guru harus cermat dalam memperhitungkan jarak tempuh antara sekolah dengan lokasi candi Simangambat.

e. Petunjuk teknis pelaksanaan; untuk taknis pelaksanaan bisa dilakukan langkah-langkah berikut ini: a] harus mendapatkan izin dari Dinas Pendidikan Nasional setempat, b] harus ada izin dari Kepala Sekolah, c] harus seizin dan setahu orang tua peserta didik, d] harus ada izin dari Yayasan [ini khusus untuk sekolah swasta].

\section{KESIMPULAN}

Situs cagar budaya adalah lokasi yang berada di darat dan/atau di air yang mengandung Benda Cagar Budaya, Bangunan Cagar Budaya, dan/atau Struktur Cagar Budaya sebagai hasil kegiatan manusia atau bukti kejadian pada masa lalu. Situs cagar budaya memiliki bentuk dan jenis yang beraneka ragam.

Setiap peninggalan bersejarah dapat dijadikan media pembelajaran dalam proses belajar-mengajar. Setiap guru memiliki kebebasan dalam memilih dan menentukan media pembelajaran yang 
digunakan saat mengajar. Peninggalan bersejarah yang terbaik dijadikan media pembelajaran adalah peninggalan bersejarah yang terdekat dengan sekolah.

Situs cagar budaya dapat difungsikan sebagai media pembelajaran dalam membangun karakter peserta didik mencintai peninggalan bersejarah. Pemanfaatan media ini dalam proses belajar-mengajar harus mendapatkan izin sekaligus dukungan berbagai pihak terutama Dinas Pendidikan setempat, Kepala sekolah dan orang tua peserta didik. Saat mengikuti proses belajarmengajar mempergunakan media pembelajaran situs cagar budaya atau peninggalan bersejarah peserta didik tidak belajar tetapi mereka juga merasakan rekreasi atau berwisata dan ini sekaligus bisa memancing atau membangkitkan bakat pada diri peserta didik.

\section{DAFTAR PUSTAKA}

Ariningsih, Indun \& Rizki Amalia, 2020, Membangun Karakter Siswa Melalui Pembelajaran Matematika Yang Berintegrasi Keislaman, JOTE Volume 1 Nomor 2 Tahun 2020

Dep. Pendidikan Nasiona, [2008], Kamus Besar Bahasa Indonesia, Jakarta, PT Gramedia Pusta Utama

Moleong, Lexy J, 2011, Metode Penelitian Kualitatif [Edisi Revisi], Bandung, PT Remaja Rosdakarya

Nurgiansah, T. H. (2021). Pendidikan Pancasila. In Solok: CV Mitra Cendekia Media.

Putry, Raihan, 2018, Nilai Pendidikan Karakter Anak Di Sekolah Perspektif Kemendiknas, Gender Equality: Internasional Journal of Child and Gender Studies, Vol. 4, No. 1, Maret 2018 Soedewo, Ery dan Andri Restiyadi, 2018, Candi Simangambat Candi Hindu Berlanggam Arsitektur Jawa Di Mandailing Natal Sumatera Utara, [jurnal], Medan, Balai Arkeologi Sumatera Utara

Undang-Undang Nomor 11Tahun 2011 Tentang Cagar Budaya

Undang-Undang No. 20 Tahun 2003 Tentang Sistem Pendidikan Nasional 